\title{
Evaluation of olfactory memory after coronary artery bypass grafting
}

\author{
Kemalettin Erdem ${ }^{1}$, Veysel Yurttas ${ }^{2}$, Murat Bilgi ${ }^{3}$, Abdullah Demırhan $^{3}$, Tayfun Apuhan ${ }^{2}$, Onursal Bugra ${ }^{1}$, \\ Bahadir Daglar ${ }^{1}$ \\ ${ }^{1}$ Department of Cardiovascular Surgery, Abant Izzet Baysal University Medical School, Bolu, Turkey \\ ${ }^{2}$ Department of Otorhinolaryngology, Head and Neck Surgery, Abant Izzet Baysal University Medical School, \\ Bolu, Turkey \\ ${ }^{3}$ Department of Anesthesiology and Critical Care, Abant Izzet Baysal University Medical School, Bolu, Turkey
}

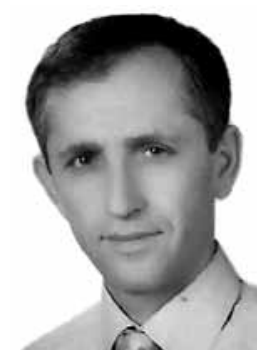

Kardiochirurgia i Torakochirurgia Polska 2014; 11 (4): 381-384

\begin{abstract}
Introduction: This study determined whether coronary artery bypass grafting $(C A B G)$ surgery has any effect on olfactory function, employing the Brief Smell Identification Test (B-SIT). Material and methods: All the participants were informed preoperatively about the B-SIT test and the mode of its application. The test was performed by each patient preoperatively (d0) as well as 1 (d1) and 3 (d3) days following the surgery. $\mathrm{C}$-reactive protein (CRP) levels were recorded at the same time as the smell test.

Results: This prospective study included 45 patients. The mean age was $67 \pm 7.55$, and the group was $29 \%$ male. The mean durations of cross clamping and cardiopulmonary bypass were $54 \pm 32 \mathrm{~min}$ and $62.5 \pm 37.0 \mathrm{~min}$, respectively. Eleven different odors were tested. Significant differences were observed for several odors: leather between $\mathrm{d} 0$ and $\mathrm{d} 3$, pine between $\mathrm{d} 0$ and $\mathrm{d} 3$, onion between $\mathrm{d} 0$ and $\mathrm{d} 1$, onion between $\mathrm{d} 0$ and $\mathrm{d} 3$, and soap between $\mathrm{d} 0$ and $\mathrm{d} 1$. The postoperative CRP levels were significantly higher than the preoperative levels. The correlation analysis determined that the postoperative CRP levels were negatively correlated with the B-SIT score $(r=-0.48, p=0.001)$. Conclusions: Our findings suggest that patients after CABG are prone to develop olfactory dysfunction in the early postoperative period and that olfactory dysfunction is associated with postoperative CRP levels.
\end{abstract}

Key words: CABG, olfactory dysfunction, CRP levels.

\section{Introduction}

Cardiovascular disease is a leading cause of death, and coronary artery bypass grafting (CABG) is the standard treatment for patients with advanced coronary artery

\section{Streszczenie}

Wstęp: Celem niniejszej pracy było zbadanie za pomocą testu B-SIT (Brief-Smell Identification Test ${ }^{T M}$ ), czy operacje pomostowania aortalno-wieńcowego (coronary artery bypass grafting - CABG) mają wpływ na zmysł węchu.

Materiat i metody: Wszystkim uczestnikom przed operacją przedstawiono informacje o teście B-SIT i sposobie jego wykonania. Test wykonywano u każdego z pacjentów przedoperacyjnie (d0) oraz 1 (d1) i 3 (d3) dni po operacji. Stężenie białka C-reaktywnego (C-reactive protein - CRP) badano w tym samym czasie co zmysł węchu.

Wyniki: W prospektywnym badaniu wzięło udział 45 pacjentów. Ich średni wiek wyniósł $67 \pm 7,55$ roku; $29 \%$ badanych stanowili mężczyźni. Czas zakleszczenia i czas użycia płucoserca wyniosły odpowiednio $54 \pm 32$ minuty i $62,5 \pm 37$ minut. Przetestowano 11 różnych zapachów. W przypadku kilku z nich wystąpiły znaczące różnice pomiędzy badaniami: skóra (między d1 a d3), sosna (między d0 a d3), cebula (między d0 a d1), cebula (między d0 a d3) oraz mydło (między d0 a d1). Pooperacyjne stężenia CRP były znacznie większe niż stężenia przedoperacyjne. Wykonana analiza korelacji pozwoliła na ustalenie, że pooperacyjne stężenia CRP były negatywnie skorelowane $z$ wynikiem testu B-SIT.

Wnioski. Wyniki wskazują, że pacjenci po operacjach CABG są narażeni na zaburzenia węchu we wczesnym okresie pooperacyjnym, a ponadto, że zaburzenia węchu są powiązane z pooperacyjnym stężeniem CRP.

Słowa kluczowe: CABG, zaburzenia węchu, stężenie CRP.

disease [1]. In addition to the general risks of surgery, onpump CABG presents the risk of complications specific to this procedure. There are many risks associated with the use of the pump, including bleeding, blood clots, stroke, kidney or lung damage, and death.

Address for correspondence: Dr. Kemalettin Erdem, Department of Cardiovascular Surgery, Abant Izzet Baysal University Medical School, 14280 Golkoy, Bolu, phone: +90 37425346 56/3387, e-mail: drkemalettincvs@yahoo.com 
Olfactory disorders occur at the rate of approximately $5 \%$ in the general population [2]. The sense of smell may be influenced by many factors, such as upper respiratory infections, head trauma, or nasal and paranasal sinus diseases. Additional factors that can influence olfactory function include age, sex, smoking behavior, and neurodegenerative diseases [3].

It has been suggested that the use of the cardiopulmonary bypass pump can cause neurocognitive dysfunction in some patients [4]. However, no study has researched the effect of CABG on olfactory function. In this study, we evaluated the effect of CABG on olfactory memory, using the Brief Smell Identification Test (B-SIT).

\section{Material and methods \\ Ethical considerations}

This study was conducted at the Department of Cardiovascular Surgery of the Abant Izzet Baysal University Hospital. Ethical approval was granted by the local research ethics committee of the Abant Izzet Baysal University, Bolu, Turkey (No: 2012/115). Written consent was obtained from each patient. This was a prospective clinical study with 45 patients undergoing elective CABG.

Exclusion criteria included structural and infectious diseases of the nose (septum deviation, polyps, and rhinitis) as well as renal, hepatic, neurological, or psychiatric disorders and prolonged intubation ( $>8$ hours). Prospective evaluations started with an initial baseline evaluation (d0), followed by two evaluations on the first (d1) and third (d3) postoperative day.

\section{Evaluation of olfactory capacity}

Olfactory function was evaluated using the B-SIT. Twelve odorants were presented to blinded patients at a distance of $2 \mathrm{~cm}$ from the nostrils for $2-3 \mathrm{~s}$. The odors were presented at intervals of at least 1 min to prevent olfactory desensitization. The test was designed as a triple forced/multiplechoice test, and the answers were recorded on a computer.

The test consists of a small book with 12 different odorants that are released when scratched with the tip of a pencil. For each odor, the patient is given four different choices with only one correct answer. If the odorant is not identified among the choices, one of the answers must still be selected [5]. The smell diskette odors that we used included mint, honey, banana, lemon, garlic, clove, lilac, leather, strawberry, coffee, chocolate, pine, vanilla, peach, fume (smoggy), cinnamon, soot, grass, peaches, rose, grapes, black pepper, melon, watermelon, peanut, soap, baby powder, chewing gum, and pineapple.

All the participants were informed preoperatively about the B-SIT and the method of its performance. Each patient underwent the test preoperatively, and the scores were recorded. Evaluations included routine clinical and laboratory tests, including tests for C-reactive protein (CRP) levels, a subjective olfactory function test, the B-SIT, and a nasal examination by an otolaryngologist.

\section{Surgical method}

The same anesthetic, surgical, and cardiopulmonary bypass (CPB) protocols were used for all patients. Between August 2012 and March 2013, 45 patients underwent onpump CABG. Anesthesia was induced with $0.50 \mu \mathrm{g} / \mathrm{kg}$ remifentanil, $0.10 \mathrm{mg} / \mathrm{kg}$ midazolam, $3.00 \mathrm{mg} / \mathrm{kg}$ thiopental, and $0.90 \mathrm{mg} / \mathrm{kg}$ rocuronium. The patients were maintained with $0.25-0.50 \mu \mathrm{g} / \mathrm{kg} / \mathrm{h}$ remifentanil and a 3.00-6.00 mg/ $\mathrm{kg} / \mathrm{h}$ propofol infusion via median sternotomy. Then, aortic cannulation was introduced, and a single right atrial cannula was inserted and connected to a membrane oxygenator (Dideco Avant 903). A single cross-clamp was placed on the aorta, and retrograde blood cardioplegia was performed every 15 min via the coronary sinus. A roller pump was used, and mild systemic hypothermia was maintained $\left(32-34^{\circ} \mathrm{C}\right)$. After $\mathrm{CPB}$, heparin sodium was antagonized with protamine sulfate at the ratio of $1 \mathrm{mg}$ protamine sulfate/ $1 \mathrm{mg}$ heparin. The preferred inotropic agents included dopamine, adrenaline, noradrenaline, and an intra-aortic balloon pump. The preferred vasodilator was nitroglycerin; when necessary, it was followed by sodium nitroprusside. Oxygen was continuously delivered to all patients in the intensive care unit at the rate of $3 \mathrm{l} / \mathrm{min}$ via a nasal cannula and was administered intermittently when oxygen saturation decreased below 95\%. Cross-clamp time, CPB time, and the use of blood and blood products were also considered.

\section{Statistical analysis}

Data analysis was performed using Windows SPSS 15.0 (SPSS Inc., Chicago, IL, USA). Descriptive variables with continuous measurements (e.g., age, OAB) are expressed as mean \pm standard deviation, while case number (\%) is used for categorical variables (e.g., B-SIT scores). A pairedsamples $t$-test was used to compare the averages of repetitive continuous variables. The significance of the difference between categorical variables was analyzed using a $\chi^{2}$ test. Pearson's correlation test was used for normally distributed variables. A $p$ value $<0.05$ was considered statistically significant.

\section{Results}

Forty-five patients were prospectively included in this study. Their mean age was $67 \pm 7.55$ years, and $29 \%$ were male. The mean cross-clamp and CPB times were $54 \pm 32 \mathrm{~min}$ and $62.5 \pm 37.0 \mathrm{~min}$, respectively. Other patient demographics and clinical characteristics are presented in Table I. No patient features were lower compared to the preoperative baseline characteristics. One patient who was unwilling to participate in the study, four patients with previous surgical treatment for nasal polyposis, three patients who developed postoperative septicemia, and one patient with prolonged intubation were excluded from the study. Evaluation of olfactory memory was established using the B-SIT test on $\mathrm{d} 1$ and $\mathrm{d} 3$, using the preoperative test results as the baseline. Significant differences were observed for several odors: leather between $\mathrm{d} 0$ and $\mathrm{d} 3$, pine between $\mathrm{d} 0$ and $\mathrm{d} 3$, 
onion between $\mathrm{d} 0$ and $\mathrm{d} 1$, onion between $\mathrm{d} 0$ and $\mathrm{d} 3$, and soap between $\mathrm{d} 0$ and $\mathrm{d} 1$. The postoperative CRP levels were significantly higher than the preoperative levels. The Pearson correlation analysis demonstrated that the CRP levels were negatively correlated with the B-SIT score $(r=-0.48$, $p=0.001$ ) (Fig. 1).

\section{Discussion}

Olfactory dysfunction after CABG may result in decreased appetite leading to weight loss, malnutrition, and impaired immunity $[6,7]$. In older patients, poor nutrition is a common problem [8]. A decreased appetite can worsen co-morbidities in these patients. Nutrition is becoming more significant because of the increased number of older patients undergoing CABG.

The first-order neurons of the olfactory system are located in the nasal mucosa [9]. A clear nasal passage is a prerequisite for normal olfactory function [10]. Inflammation of the olfactory epithelium also affects olfactory function in addition to mechanical obstruction [11]. Nasal inflammation due to allergic, viral, or bacterial etiology is the most common cause of olfactory dysfunction in the general population $[12,13]$. Sultan et al. [14] used a transgenic mouse model of olfactory inflammation induced by tumor necrosis factor $\alpha$ (TNF- $\alpha)$ to examine the effect of systemic inflammation on olfactory function. They reported that TNF- $\alpha$ caused physiological dysfunction in olfactory neurons. Some studies indicated that not only inflammation but also emotional status may influence olfactory function. For example, Zald et al. demonstrated that olfactory function is strongly associated with emotion [15]. The emotional condition of our patients may have affected the test responses in this study.

C-reactive protein is another marker for inflammation and an acute-phase reactant. Ramlawi et al. [16] found that the incidence of neurocognitive deficiency after CABG was significantly associated with CRP elevation. They claimed that increased CRP was not the cause of brain injury, but rather was triggered in response to brain injury. Some argue that cognitive dysfunction after CPB is a cerebral inflammatory phenomenon $[17,18]$. Similarly, we detected that the postoperative CRP levels were significantly higher than the preoperative levels in all patients. We also found that the postoperative CRP levels were higher in patients with olfactory dysfunction. We believe that these inflammatory markers might have played an important role in the development of olfactory dysfunction in our study population.

The B-SIT test was developed as a useful tool to measure odor identification deficits. The test is a brief, easily administered, and convenient instrument derived from the 40-item University of Pennsylvania Smell Identification Test. Many tests have been used previously for the evaluation of olfactory function. The evaluation of the olfactory function of patients, based on odor recognition, is the most important part of the test. Previous studies have shown that B-SIT has a sensitivity and specificity of $82 \%$. Therefore, the present study employed it to ensure appropriate
Tab. I. Baseline and clinical characteristics of study group

\begin{tabular}{lc} 
Factor* & $n(\%)$ \\
\hline Number of patients $(n)$ & 45 \\
\hline Age (years) & $67 \pm 7.55$ \\
\hline Male & $29(64.4)$ \\
\hline Female & $16(35.6)$ \\
\hline Diabetes mellitus & $21(46.7)$ \\
\hline Smoking & $16(35)$ \\
\hline$\beta$-blocker use & $20(44.4)$ \\
\hline ACE or ARB use & $22(48.9)$ \\
\hline Calcium channel blocker use & $11(24.4)$ \\
\hline Antihyperlipidemic therapy & $19(42.2)$ \\
\hline Ejection fraction (\%) & $49 \pm 9.29$ \\
\hline Body mass index (kg/m $\left.{ }^{2}\right)$ & $25.0 \pm 5.5$ \\
\hline Cross clamp time (min) & $54 \pm 32$ \\
\hline CPB time (min) & $62.5 \pm 37$ \\
\hline Number of vessels & $3.5 \pm 1.15$ \\
\hline Number of patients requiring inotropic support & $10(22)$ \\
\hline Erythrocyte suspension & $6.5 \pm 4.9$ \\
\hline
\end{tabular}

*Values are expressed as mean \pm SD or $n(\%)$.

$\mathrm{ACE}$ - angiotensin-converting enzyme inhibitor, $\mathrm{ARB}$ - angiotensin receptor blockers, CPB - cardiopulmonary bypass



Fig. 1. The Pearson correlation analysis demonstrated that the CRP levels were negatively correlated with the B-SIT score

odor evaluation. The study revealed that the postoperative CRP levels were statistically significantly negatively correlated with the B-SIT score.

Our results suggest that increased postoperative CRP levels are associated with the development of olfactory dysfunction. Additionally, our findings suggest that patients after CABG are prone to develop olfactory dysfunction in the early postoperative period.

The first limitation of this study was the lack of a control group. Secondly, the test protocol involved making a com- 
pulsory choice from four options, leaving a $25 \%$ chance that the patient chose the correct answer at random. Diabetes mellitus influencing the inflammatory status and the learning effect may also have affected our results. Finally, we evaluated CRP levels as the only parameter of inflammation; we did not use other inflammation markers.

To our knowledge, this is the first study to evaluate the olfactory function in patients undergoing CABG. It revealed that olfactory dysfunction may occur during the early postoperative period after CABG and that this condition is associated with postoperative CRP levels.

\section{Disclosure}

Authors report report no conflict of interest.

\section{References}

1. Favaloro RG. Saphenous vein autograft replacement of severe segmental coronary artery occlusion: operative technique. Ann Thorac Surg 1968; 5: 334-339.

2. Landis BN, Konnerth CG, Hummel T. A study on the frequency of olfactory dysfunction. Laryngoscope 2004; 114: 1764-1769.

3. Deems DA, Doty RL, Settle RG. Smell and taste disorders, a study of 750 patients from the University of Pennsylvania Smell and Taste Center. Arch Otolaryngol Head Neck Surg 1991; 117: 519-528.

4. Selnes OA, McKhann GM. Neurocognitive complications after coronary artery bypass surgery. Ann Neurol 2005; 57: 615-621.

5. Krantz EM, Schubert CR, Dalton DS, Zhong W, Huang GH, Klein BE, Klein R, Nieto FJ, Cruickshanks KJ. Test-retest Reliability of the San Diego Odor
Identification Test and Comparison with the Brief Smell Identification Test. Chem Senses 2009; 34: 435-440.

6. Mavi A, Ceyhan O. Bitter taste thresholds, numbers and diameters of circumvallate papillae and their relation with age in a Turkish population. Gerodontology 1999; 16: 119-122.

7. Miletic ID, Schiffman SS, Miletic VD, Sattely-Miller EA. Salivary IgA secretion rate in young and elderly persons. Physiol Behav 1996; 60: 243-248.

8. Stevens JC, Cain WS, Demarque A, Ruthruff AM. On the discrimination of missing ingredients: aging and salt flavour. Appetite 1991; 16: 129-140.

9. Gottfried JA. Smell: central nervous processing. Adv Otorhinolaryngol 2006; 63: 44-69.

10. Knecht M, Hüttenbrink KB, Hummel T. Smell and taste disorders. Schweiz Med Wochenschr 1999; 129: 1039-1046.

11. Stevens MH. Steroid-dependent anosmia. Larynoscope 2001; 111: 200-203.

12. Damm M, Temmel A, Welge-Lüssen A, Eckel HE, Kreft MP, Klussmann JP, Gudziol H, Hüttenbrink KB, Hummel T. Olfactory dysfunctions. Epidemiology and therapy in Germany, Austria and Switzerland. HNO 2004; 52: 112-120.

13. Nordin S, Murphy C, Davidson TM, Quiñonez C, Jalowayski AA, Ellison DW. Prevalence and assessment of qualitative olfactory dysfunction in different age groups. Laryngoscope 1996; 106: 739-742.

14. Sultan B, May LA, Lane AP. The role of TNF- $\alpha$ in inflammatory olfactory loss. Laryngoscope 2011; 121: 2481-2486.

15. Zald DH, Pardo JV. Emotion, olfaction, and the human amygdala: amygdala activation during aversive olfactory stimulation. Proc Natl Acad Sci 1997; 94: 4119-4124.

16. Ramlawi B, Rudolph JL, Mieno S, Khabbaz K, Sodha NR, Boodhwani M, Levkoff SE, Marcantonio ER, Sellke FW. Serologic markers of brain injury and cognitive function after cardiopulmonary bypass. Ann Surg 2006; 244 : 593-601.

17. Grocott HP, Homi HM, Puskas F. Cognitive dysfunction after cardiac surgery: revisiting etiology. Semin Cardiothorac Vascular Anesth 2005; 9: 123-129.

18. Gao L, Taha R, Gauvin D, Othmen LB, Wang Y, Blaise G. Postoperative cognitive dysfunction after cardiac surgery. Chest 2005; 128: 3664-3670. 